\title{
Contribution of a Common Variant in the Promoter of the $1-\alpha$-Hydroxylase Gene $($ CYP27B1) to Fracture Risk in the Elderly
}

\author{
Roderick J. Clifton-Bligh • Tuan V. Nguyen • Amy Au • Martyn Bullock • \\ Ian Cameron - Robert Cumming • Jian Sheng Chen - Lyn M. March • \\ Markus J. Seibel · Philip N. Sambrook
}

Received: 3 February 2010/ Accepted: 22 September 2010/Published online: 25 November 2010

(C) The Author(s) 2010. This article is published with open access at Springerlink.com

\begin{abstract}
CYP27B1 encodes mitochondrial $1 \alpha$-hydroxylase, which converts 25 -hydroxyvitamin D to its active 1,25 dihydroxylated metabolite. We tested the hypothesis that common variants in the CYP27B1 promoter are associated with fracture risk. The study was designed as a populationbased genetic association study, which involved 153 men and 596 women aged 65-101 years, who had been followed for 2.2 years (range 0.1-5.5) between 1999 and 2006. During the follow-up period, the incidence of fragility fractures was ascertained. Bone ultrasound attenuation (BUA) was measured in all individuals, as were serum 25-hydroxyvitamin D and PTH concentrations; $86 \%$ subjects had vitamin $\mathrm{D}$ insufficiency. Genotypes were determined for the $-1260 \mathrm{C}>\mathrm{A}(\mathrm{rs} 10877012)$ and $+2838 \mathrm{~T}>\mathrm{C}(\mathrm{rs} 4646536)$ $C Y P 27 B 1$ polymorphisms. A reporter gene assay was used to assess functional expression of the $-1260 \mathrm{C}>\mathrm{A}$ CYP27B1
\end{abstract}

Roderick J. Clifton-Bligh, Tuan V. Nguyen and Amy Au contributed equally to this work.

The authors have stated that they have no conflict of interest.

R. J. Clifton-Bligh

Northern Metabolic Bone Research Unit, Royal North Shore

Hospital, St. Leonards, NSW, Australia

R. J. Clifton-Bligh $(\bowtie) \cdot$ A. Au · M. Bullock ·

L. M. March · P. N. Sambrook

Kolling Institute of Medical Research, Royal North Shore

Hospital, St. Leonards, NSW 2067, Australia

e-mail: jclifton@med.usyd.edu.au

I. Cameron

Rehabilitation Studies Unit, The University of Sydney at

Concord, Sydney, Australia

R. Cumming

School of Public Health, The University of Sydney at Concord,

Sydney, Australia variants. The association between genotypes and fracture risk was analyzed by Cox's proportional hazards model. We found that genotypic distribution of CYP27B1 -1260 and CYP27B1 +2838 polymorphisms was consistent with the Hardy-Weinberg equilibrium law. The two polymorphisms were in high linkage disequilibrium, with $\mathrm{D}^{\prime}=0.96$ and $r^{2}=0.94$. Each $C$ allele of the CYP27B1 -1260 polymorphism was associated with increased risk of fracture (hazard ratio $=1.34,95 \%$ CI 1.03-1.73), after adjustment for age, sex, number of falls, and BUA. In transient transfection studies, a reporter gene downstream of the -1260(A)-containing promoter was more highly expressed than that containing the $C$ allele. These data suggest that a common but functional variation within the $C Y P 27 B 1$ promoter gene is associated with fracture risk in the elderly.

Keywords Vitamin D $\cdot 1 \alpha$-Hydroxylase $\cdot$ CYP27B1 . Osteoporosis · Fracture

\author{
J. S. Chen \\ Institute of Bone and Joint Research, Royal North Shore \\ Hospital, St. Leonards, NSW 2067, Australia \\ M. J. Seibel \\ Bone Research Program, ANZAC Research Institute, The \\ University of Sydney at Concord, Sydney, Australia \\ T. V. Nguyen \\ Garvan Institute of Medical Reseach, St. Vincent's Hospital, \\ Darlinghurst, NSW, Australia \\ T. V. Nguyen \\ University of New South Wales, Sydney, NSW, Australia
}


Several epidemiologic studies have consistently demonstrated that fracture tends to cluster within families but the segregation does not follow a Mendelian pattern [1]. Women whose mother had a hip fracture are at increased risk of hip fracture compared to those whose mothers did not sustain a fracture [2]. Approximately $25-35 \%$ of the variance of fracture liability is attributable to genetic factors $[3,4]$. Genetic factors also account for a large proportion of variance in risk factors of fracture such as bone mineral density (BMD) [5], bone loss [6], quantitative ultrasound measurement [7], and bone turnover markers [8].

Specific genes involved in the regulation of bone mass and fracture susceptibility have been identified on the basis of candidate gene-association studies, such as collagen $1 \alpha 1$ [9] and lipoprotein receptor-related protein 5 (LRP5) [10]. More recently, with the advance of genomewide studies, a number of single-nucleotide polymorphisms (SNPs) have been associated with fracture and bone density [11-14]. Such studies have shown an association between osteoporosis and SNPs within genes encoding osteoprotegerin, LRP5, estrogen receptor 1 , and receptor activator of nuclear factor- $\kappa$ B ligand [11-14]. One genomewide study provided some evidence for an association between vitamin D receptor $(V D R)$ variants and BMD [11], which was first identified by Morrison and colleagues $[15,16]$ but has been controversial since [17].

One limitation, however, of current genomewide studies has been incomplete coverage of genetic variation, such that the replicated SNP associations explain only a small proportion of the variance in BMD and fracture [18]. This suggests the existence of other sequence variants that are associated with osteoporosis, and there is still a role therefore in studying key candidate genes within physiologic pathways known to influence skeletal health. For instance, vitamin D is undoubtedly critical for optimal skeletal mineralization [19], and its active product is generated by $1 \alpha$-hydroxylation of 25 -hydroxyvitamin D [20]. Coding region mutations in the CYP27B1 gene encoding $1 \alpha$-hydroxylase cause type I vitamin D-dependent rickets $[21,22]$. Moreover in two large, separate studies a SNP in the CYP27B1 promoter (rs10877012) was recently associated with multiple sclerosis [23] and type 1 diabetes [24]; the same allele was responsible for the disease association in each case and was also associated with other autoimmune disorders in smaller studies [25-29]. Since vitamin D deficiency is increasingly common in the elderly and a risk factor for fracture in postmenopausal women [30], we hypothesized that $C Y P 27 B 1$ is associated with fracture risk in the elderly. The present study was therefore designed to test the hypothesis by examining the association between $C Y P 27 B 1$ gene polymorphisms and fracture risk in a cohort of frail elderly subjects, a majority of whom were vitamin D-insufficient.

\section{Study Design and Methods}

\section{Participants}

The Fracture Risk Epidemiology in the Frail Elderly (FREE) Study is an ongoing prospective study of predictors of falls and fractures in a cohort of men and women living in residential care facilities in Sydney [31]. Ethical approval was given by the local institutional Human Research Ethics Committee. Not all of the 2,005 participants in the FREE study were able to give consent for venesection, but all participants who had blood collected at the baseline are reported here. Of these, 760 of 915 subjects had DNA available for genotyping.

\section{Measurements}

Fracture was ascertained through chart review during regular visits to institutions (i.e. once every 6-12 weeks) for 2 years from baseline and validated by review of a radiology report. The diagnosis of clinical vertebral fractures required subjects to have radiologic evidence of vertebral fracture in association with acute back pain at a corresponding level, but a previous normal X-ray at that vertebral level was not required. For the purpose of these analyses, the following fractures were included: hip, clinical vertebral, pelvis, wrist, humeral, rib, and femoral shaft. Fractures of the skull, ankle, finger, and hand were excluded from the analysis. Falls were ascertained from incident reports and medical records (examined every 6-12 weeks).

Clinical biochemistry and calcaneal ultrasound measurements have been previously described [31]. Briefly, morning blood samples were collected at baseline assessment. Serum 25 -hydroxyvitamin D was measured by RIA (DiaSorin, Stillwater, MN). Serum PTH was measured by a two-site chemiluminescent ELISA on an Immulite 1000 analyzer (Diagnostic Products, Los Angeles, CA). Bone ultrasound attenuation (BUA) was measured at the calcaneus in all participants using a MCue CUBA Mark II ultrasound device [31].

\section{Genotyping}

We studied the SNP rs10877012, which lies $1.2 \mathrm{~kb}$ upstream of the transcription start site of CYP27B1 $(-1260 \mathrm{C}>\mathrm{A})$ and was strongly associated with either type 1 diabetes or multiple sclerosis in two large genotyping studies [23, 24]. This SNP is predicted to cause a functional change using the bioinformatics tool F-SNP, which makes predictions of functionality of variants located within putative transcription factor binding sites (TFBSs) [32]. Moreover, other SNPs within or up to $10 \mathrm{~kb}$ upstream of the CYP27B1 gene locus (HapMap) are either in near- 
complete linkage disequilibrium with rs10877012 (D' 1.0 and $r^{2}>0.98$ ), unlikely to be functional by F-SNP (intronic rs4646537, MAF 0.034; synonymous exon rs8176345, MAF 0.049), or rare (MAF $<0.01)$. We had also previously genotyped this cohort for another intragenic CYP27B1 SNP rs4646536 $(+2838 \mathrm{~T}>\mathrm{C}$, in intron 6), which some [24], but not all [25, 27, 28], studies had suggested was in near-perfect linkage disequilibrium with rs10877012.

Genomic DNA was extracted from peripheral blood leucocytes using standard procedures. Genomic DNA was amplified by PCR (with an annealing temperature of $60^{\circ} \mathrm{C}$ in all cases), and genotyping was conducted by restriction fragment length polymorphism. The $C Y P 27 B 1-1260$ SNP was amplified using primers forward $5^{\prime}$-GGC ACA GAG CCT GAT AGA GTT G-3' and reverse 5'-GGC AAC ATA GTC GAA CTG TCT C- $3^{\prime}$ and detected with the HinfI enzyme. The CYP27B1 +2838 SNP was amplified using reverse primer $5^{\prime}$-TAG GTT GCA AAG CAC AAA ATG GAG TCA-3' and a mismatched forward primer 5'-GGA AGC AGG GAG ATA GCA GAG $-3^{\prime}$ that introduces a HincII restriction site in the presence of the $T$ allele. PCR products were digested for at least 2 hours at $37^{\circ} \mathrm{C}$ and electrophoresed on agarose gels. All genotypes were scored by two researchers independently (R. J. C.-B., A. A.). Repeat genotyping was conducted in 158 samples ( $21 \%$ of cohort) with $100 \%$ concordance as a quality control.

\section{Reporter Gene Studies}

A reporter construct containing the proximal $1.3 \mathrm{~kb}$ of the human CYP27B1 promoter upstream of the luciferase gene was a kind gift from Prof. Howard Morris (Hanson Institute, Adelaide, Australia) [33]. Sequencing of this construct revealed the $C$ allele at -1260 . Standard site-directed mutagenesis was performed to create another reporter containing the $-1260 A$ CYP27B1 allele (Quik-Change ${ }^{\mathrm{TM}}$; Stratagene, La Jolla, CA), and mutagenesis was confirmed by direct sequencing. Human embryonic kidney HEK293 cells in 24-well plates were transiently transfected using DMRIE-C (Invitrogen Life Technologies, Carlsbad, CA) with 10,50 , or $100 \mathrm{ng}$ of either $C Y P 27 B 1$ reporter gene $(-1260 \mathrm{~A}$ or $-1260 \mathrm{C})$ or empty reporter vector (pGL3-basic, $100 \mathrm{ng}$ ). A renilla luciferase reporter (Promega, Madison, WI), $10 \mathrm{ng} /$ well, was used to control for transfection efficiency. Cells were lysed after 48-hour incubation and then assayed for firefly and renilla luciferase activities (Promega). The transcriptional response was normalized for renilla activity, then expressed as a fold change relative to data from cells transfected with the empty pGL3-basic reporter. Data represent mean $\pm \mathrm{SD}$ of three experiments, each performed in triplicate wells.
Statistical Analysis

The association between the polymorphisms and fracture was assessed by the Cox proportional hazards model [34], in which the time to fracture was considered outcome, whereas age, weight, BUA, and biochemical markers were covariates. The metric of association was expressed in terms of hazard ratio (HR) per allele for each polymorphism. The hormonal and mineral parameters considered in the model were serum 25-hydroxyvitamin $\mathrm{D}, \mathrm{PTH}$, and calcium. Because the distribution of these parameters was skewed, a logarithmic transformation was applied to "normalize" the data and stabilize their variance prior to the modeling process. In order to estimate the proportion of fracture liability that may be hypothetically attributable to the polymorphism, the population-attributable risk fraction (PARF) was calculated according to the "sequential attributable fraction" [35]. Analyses were conducted with the R statistical language (www.r-project.org).

\section{Results}

On average, the individuals had been followed for 2.2 years (range 0.1-5.5). During the follow-up period, 21 men and 116 women had sustained a fragility fracture, with the incidence of fracture (per 100 person-years) being 6.62 for men and 9.96 for women. Baseline clinical characteristics and biochemical markers stratified by sex and fracture status are shown in Table 1. BUA was significantly reduced and fall rate was higher among women with fracture, although there was no significant difference in age and biochemical markers between the fracture and nonfracture groups.

Of an original cohort of 915 individuals, DNA was available from 760 subjects for genotyping, of which 11 samples failed to amplify, leaving a total of 749 genotyped subjects (Table 1). The relative frequency of CYP27BI -1260 alleles was $0.64 \mathrm{C}: 0.36 \mathrm{~A}$, with genotypes $A A(14 \%)$, $A C(43 \%)$, and $C C(43 \%)$. The CYP27B1 -1260 polymorphism was in tight linkage disequilibrium with the CYP27B1 +2838 polymorphism (0.65T:0.35C; $\mathrm{D}^{\prime}=0.96$, $\left.r^{2}=0.94[\mathrm{SE}=0.012]\right)$. In each polymorphism the distribution of genotypes was consistent with Hardy-Weinberg equilibrium $(P>0.15)$. There were no significant differences in age, weight, BUA, serum PTH, and creatinine among CYP27B1-1260 genotypes; serum 25(OH)D was higher in heterozygotes but not significantly different between homozygotes for either -1260 allele (Table 2). The parameters shown in Table 2 were also analyzed separately by gender (not shown), and the variation of $25(\mathrm{OH}) \mathrm{D}$ by genotype was seen only in men.

The cumulative probability of fracture for each $C Y P 27 B 1-1260$ genotype is shown in Fig. 1. Individuals 
Table 1 Baseline characteristics of participants stratified by gender and fracture status

\begin{tabular}{|c|c|c|c|}
\hline Gender & Nonfracture & Fracture & $P$ \\
\hline $\operatorname{Men}(n)$ & 132 & 21 & \\
\hline Age (years) & $84.6(7.5)$ & $86.8(7.2)$ & 0.201 \\
\hline Weight (kg) & $68.4(11.8)$ & $65.9(10.9)$ & 0.360 \\
\hline $25(\mathrm{OH}) \mathrm{D}(\mathrm{nmol} / \mathrm{l})^{*}$ & $31.0(21,44.3)$ & $26.0(17,42.3)$ & 0.232 \\
\hline $\log (25[\mathrm{OH}] \mathrm{D})$ & $3.41(0.60)$ & $3.16(0.84)$ & 0.117 \\
\hline PTH $(\mathrm{pg} / \mathrm{ml})^{*}$ & $49.6(33,72.5)$ & $42.0(29,67.1)$ & 0.771 \\
\hline $\log (\mathrm{PTH})$ & $3.93(0.66)$ & $3.87(0.75)$ & 0.772 \\
\hline Creatinine (mmol/l) & $101.0(34.8)$ & $111.3(16.1)$ & 0.239 \\
\hline Albumin $(\mathrm{g} / \mathrm{l})$ & $41.1(3.1)$ & $40.7(0.5)$ & 0.430 \\
\hline Phosphate (mmol/l) & $1.16(0.18)$ & $1.11(0.09)$ & 0.242 \\
\hline Corrected $\mathrm{Ca}(\mathrm{mmol} / \mathrm{l})$ & $2.36(0.15)$ & $2.33(0.09)$ & 0.390 \\
\hline BUA (dB/MHz) & $72.3(26.5)$ & $63.4(18.3)$ & 0.071 \\
\hline Fall rate (falls/year)* & $0.68(0,2.65)$ & $2.52(1,6.21)$ & 0.69 \\
\hline Women $(n)$ & 480 & 116 & \\
\hline Age (years) & 87. (6.4) & $87.1(5.7)$ & 0.838 \\
\hline Weight (kg) & $56.2(12.4)$ & $55.3(11.6)$ & 0.462 \\
\hline $25(\mathrm{OH}) \mathrm{D}(\mathrm{nmol} / \mathrm{l})^{*}$ & $24.0(17,36)$ & $27.5(20,39.3)$ & 0.040 \\
\hline $\log (25[\mathrm{OH}] \mathrm{D})$ & $3.18(0.58)$ & $3.32(0.55)$ & 0.017 \\
\hline PTH $(\mathrm{pg} / \mathrm{ml})^{*}$ & $58.0(39,90.6)$ & $63.7(41.2,95)$ & 0.272 \\
\hline $\log (\mathrm{PTH})$ & $4.09(0.67)$ & $4.08(0.65)$ & 0.851 \\
\hline Creatinine (mmol/l) & $88.2(32.4)$ & $85.0(29.8)$ & 0.576 \\
\hline Albumin $(\mathrm{g} / \mathrm{l})$ & $40.6(3.2)$ & $39.3(3.8)$ & 0.082 \\
\hline Phosphate (mmol/l) & $1.20(0.18)$ & $1.22(0.16)$ & 0.672 \\
\hline Corrected $\mathrm{Ca}(\mathrm{mmol} / \mathrm{l})$ & $2.39(0.13)$ & $2.40(0.13)$ & 0.725 \\
\hline BUA (dB/MHz) & $46.0(17.8)$ & $40.7(14.6)$ & 0.001 \\
\hline Fall rate (falls/year)* & $0.59(0,2.49)$ & $1.53(0.84,3.72)$ & 0.03 \\
\hline
\end{tabular}

Values are mean (SD), except for asterisked variables, for which data are median (IQR)

homozygous for the $C Y P 27 B 1-1260 \mathrm{C}$ allele experienced the highest incidence of fracture (13.9/100 person-years), followed by heterozygous individuals (11.6/100 person-

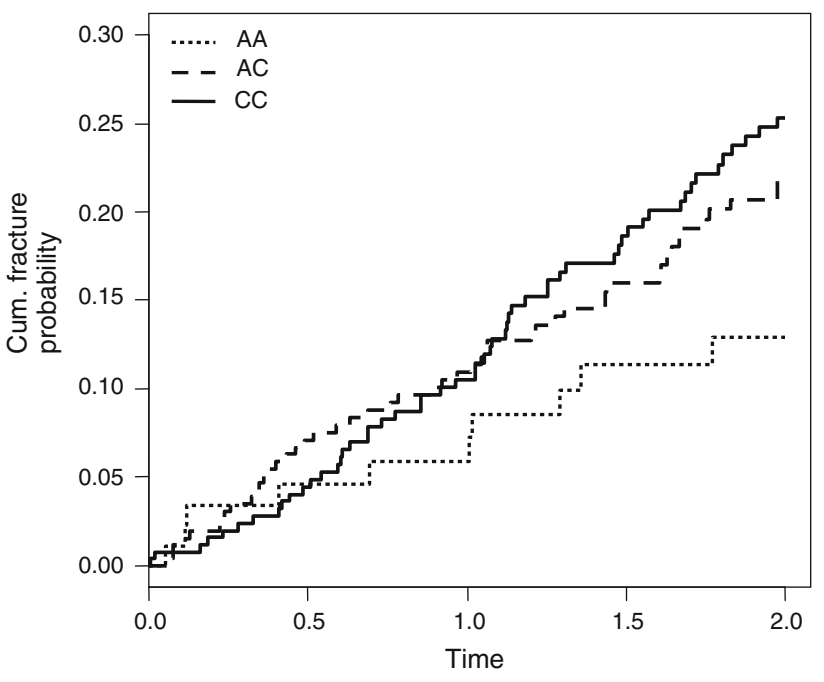

Fig. 1 Cumulative probability of fracture stratified by $C Y P 27 B 1$ -1260 genotype. Probability of fracture over time $(y)$ is expressed for each genotype (AA, short dashed line; $A C$, long dashed line; $C C$, solid line)

years) and those homozygous for the $A$ allele (7.9/100 person-years). A similar trend was also found for the CYP27B1 +2838 polymorphism (Table 3 ).

Each $C$ allele of the CYP27B1 -1260 polymorphism was associated with an increased hazard of fracture by 1.28 (95\% CI 1.00-1.66, $P=0.05$ ). The association was unchanged after adjusting for age, sex, number of falls, and BUA; when analyzed separately, the effect of CYP27B1 genotype on fracture was not significant in men, although there were far fewer fractures $(n=21)$ than in women $(n=116)$. The final predictive model is shown in Table 4, in which after adjusting for age, number of falls, and BUA, the HR associated with each $C$ allele was 1.34 (95\% CI 1.03-1.73). The number of fracture cases that can be attributed to the variation at this polymorphism was $11.4 \%$.

Table 2 Baseline characteristics of participants stratified by CYP27B1-1260C $>$ A genotype

\begin{tabular}{|c|c|c|c|c|}
\hline & $A A$ & $A C$ & $C C$ & $P$ \\
\hline$n$ & 108 & 320 & 321 & \\
\hline Age (years) & $86.8(6.8)$ & $86.5(6.2)$ & $86.9(6.9)$ & 0.78 \\
\hline Weight $(\mathrm{kg})$ & $59.0(12.2)$ & $58.1(13.4)$ & $58.5(13.0)$ & 0.81 \\
\hline $25(\mathrm{OH}) \mathrm{D}(\mathrm{nmol} / \mathrm{l})^{*}$ & $26(17,37)$ & $27(18,41)$ & $25(17,35)$ & 0.02 \\
\hline PTH $(\mathrm{pg} / \mathrm{ml})^{*}$ & $56.6(34,98.7)$ & $55.0(38,81.3)$ & $60.0(39,90.9)$ & 0.53 \\
\hline Creatinine $(\mathrm{mmol} / \mathrm{l})$ & $81.4(17.7)$ & $93.6(33.1)$ & $90.2(35.4)$ & 0.16 \\
\hline Albumin (g/l) & $39.9(3.5)$ & $40.8(3.2)$ & $40.4(3.2)$ & 0.28 \\
\hline Phosphate (mmol/l) & $1.16(0.22)$ & $1.20(0.15)$ & $1.21(0.18)$ & 0.26 \\
\hline Corrected $\mathrm{Ca}(\mathrm{mmol} / \mathrm{l})$ & $2.39(0.17)$ & $2.39(0.12)$ & $2.38(0.12)$ & 0.97 \\
\hline BUA (dB/MHz) & $48.1(17.8)$ & $49.7(20.8)$ & $51.7(24.3)$ & 0.28 \\
\hline Fall rate (falls/year)* & $0.73(0,2.50)$ & $0.82(0,2.96)$ & $0.95(0,2.82)$ & 0.25 \\
\hline
\end{tabular}

Values are mean (SD), except for asterisked variables, for which data are median (IQR) 
Table 3 Frequency distribution of genotypes in fracture and

\begin{tabular}{lcclc}
\hline Polymorphism/genotype & Nonfracture & Fracture & $\begin{array}{l}\text { Proportion } \\
\text { of fracture }(\%)\end{array}$ & $\begin{array}{l}\text { Rate of fracture } \\
\text { per 100 person-years }\end{array}$ \\
\hline CYP27B1-1260C $>$ A & & & & \\
$A A$ & 95 & 13 & 12.0 & 7.9 \\
$A C$ & 263 & 57 & 17.8 & 11.6 \\
$C C$ & 254 & 67 & 20.9 & 13.9 \\
$C Y P 27 B 1+2838 \mathrm{~T}>\mathrm{C}$ & & & & \\
$C C$ & 87 & 13 & 13.0 & 8.4 \\
$T C$ & 265 & 55 & 17.2 & 11.2 \\
$T T$ & 247 & 66 & 21.1 & 14.1 \\
\hline
\end{tabular}

Table 4 Independent predictors of fracture risk

\begin{tabular}{lllr}
\hline Risk factors & Hazard ratio & $95 \%$ CI & \multicolumn{1}{l}{$P$} \\
\hline CYP27B1 -1260 allele $^{\mathrm{a}}$ & 1.34 & $1.03-1.73$ & 0.027 \\
Age (per 5 years) & 1.05 & $0.91-1.20$ & 0.528 \\
Falls & 1.02 & $1.00-1.05$ & 0.034 \\
BUA (-20) & 1.45 & $1.21-1.75$ & $<0.001$ \\
CYP27B1 +2838 allele & 1.33 & $1.03-1.72$ & 0.027 \\
Age (per 5 years) & 1.03 & $0.90-1.18$ & 0.671 \\
Falls & 1.03 & $1.00-1.05$ & 0.023 \\
BUA (-20) & 1.46 & $1.21-1.76$ & $<0.001$ \\
\hline
\end{tabular}

a The magnitude of association is expressed per $C$ allele $(-1260)$ or $T$ allele $(+2838)$. For age and BUA, the hazard ratio was computed per 5 -year increase or $20-\mathrm{db} / \mathrm{MHz}$ decrease, respectively

\section{Reporter Studies}

We next investigated the functional effect of the $C Y P 27 B 1$ -1260 polymorphism in transfection studies using a $1.3-\mathrm{kb}$ region of the human $C Y P 27 B 1$ promoter cloned upstream of the luciferase gene [33]. We determined that the promoter contained the $C$ allele at position -1260 and performed site-directed mutagenesis to generate the $A$ allele at this position. We confirmed the integrity of the remaining sequence following mutagenesis by direct sequencing. We then transfected either reporter in increasing amounts into human kidney HEK293 cells. We expected that the functional change associated with the $-1260 \mathrm{C}>\mathrm{A}$ SNP would be subtle (as any SNP associated with a complex phenotype) and, therefore, may only be apparent at limiting doses of the promoter. As shown in Fig. 2, the reporter gene containing the CYP27B1-1260A allele was expressed significantly more than that containing the $-1260 \mathrm{C}$ allele; at plasmid doses of $10-50 \mathrm{ng} /$ well, the $-1260 \mathrm{C}$ reporter was only $70-80 \%$ as active as the $-1260 \mathrm{~A}$-containing reporter and, as expected, the difference was lost when higher concentrations ( $\geq 100 \mathrm{ng}$ ) of each reporter was used.

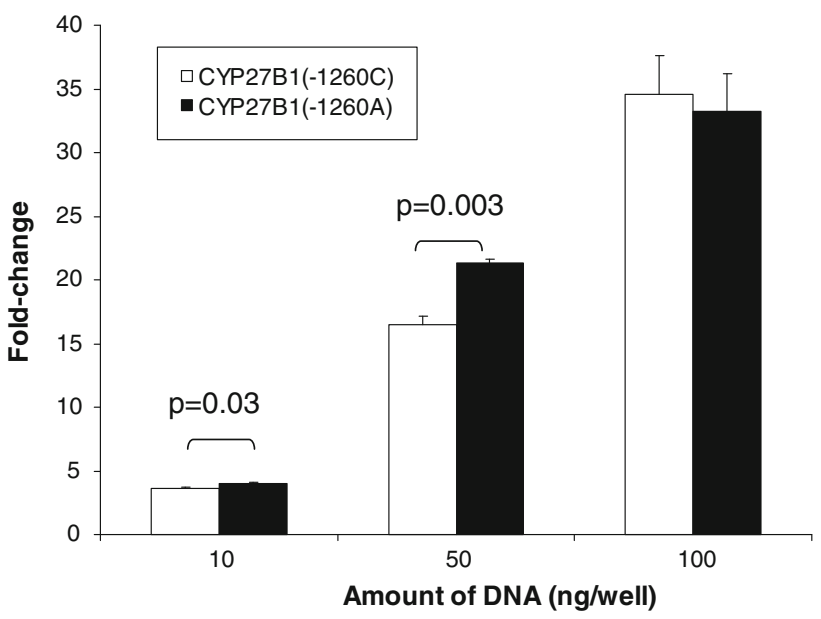

Fig. $2 C Y P 27 B 1$ promoter activity in vitro. HEK293 cells were transfected with a luciferase reporter gene with the 1.3-kb CYP27BI promoter containing either the $-1260 \mathrm{C}$ or the $-1260 \mathrm{~A}$ allele. Luciferase expression in each case was normalized for an internal transfection control (renilla) and expressed relative to activity from cells transfected with the empty reporter plasmid (pGL3-basic). Data are mean $\pm \mathrm{SD}$ of three experiments, each performed in triplicate wells. CYP27B1 -1260C allele, white bars; CYP27B1-1260A allele, solid bars. Significance was determined by Student's $t$-test

\section{Discussion}

Vitamin D is important for skeletal health across all ages. During infancy and childhood, vitamin D deficiency leads to rickets and osteomalacia. In adults, and particularly in the elderly, vitamin D deficiency is a key risk factor for osteoporotic fractures, and the mechanisms are complex and may not be solely translated via the known skeletal effects of vitamin D [36]. The present study represents the first demonstration of an association between SNPs in the $C Y P 27 B 1$ gene and fracture risk in frail elderly subjects. The strongest association was with a SNP in the $C Y P 27 B 1$ promoter $(-1260 \mathrm{C}>\mathrm{A})$; association with a second, intronic SNP $(+2838 \mathrm{~T}>\mathrm{C})$ could be explained by tight linkage disequilibrium between the two SNPs, consistent with the study by Bailey et al. [24]. Our functional data that the $-1260 \mathrm{C}$ allele leads to lower gene expression is consistent 
with another recent study that found lower $C Y P 27 B 1$ mRNA expression in peripheral blood mononuclear cells from type 1 diabetic patients homozygous for the $-1260 \mathrm{C}$ allele [26]. Moreover, the $-1260 \mathrm{C}$ allele changes a consensus CDX2 transcription factor binding site within the CYP27B1 promoter [29], and a CDX2-binding site polymorphism within the $V D R$ promoter $[37,38]$ has recently been significantly associated with vertebral fracture in a large multicenter study [39]. The functional consequence of the CYP27B1 -1260C allele (Fig. 2) is similar in magnitude to that reported for the VDR CDX2 polymorphism in vitro [37]. Taken together, we propose that the CYP27B1 $-1260 \mathrm{C}$ SNP is associated with skeletal fragility via reduced expression of $1 \alpha$-hydroxylase, in particular since the majority of our subjects were vitamin D-insufficient.

Further arguments in favor of a functional effect of this SNP include reports that the same $C Y P 27 B 1-1260 \mathrm{C}$ allele is associated with type 1 diabetes [24-26] and other endocrine autoimmune disorders [27-29]. In the largest study, CYP27B1-1260C was associated with an increased risk of type 1 diabetes in 7,854 cases compared with 8,758 controls $(\mathrm{OR}=1.07)$, and in 2,774 affected families $(\mathrm{RR}=1.11)$, with the combined association at $P=3.8 \times 10^{-6}$ [24]. There is strong evidence that vitamin $\mathrm{D}$ deficiency is associated with type 1 diabetes [40]. The association of the CYP27B1-1260C variant with diabetes has been proposed to be due to lower systemic availability of calcitriol or alternatively to reduced $C Y P 27 B 1$ expression in immune regulatory cells [41].

The association between the CYP27B1 $-1260 \mathrm{C}$ allele and fracture in our study might also therefore be mediated via reduced $C Y P 27 B 1$ expression within the kidney leading to reduced circulating calcitriol concentrations. Arguing against this possibility, however, is that serum PTH concentrations were not significantly higher in subjects with the $-1260 \mathrm{C}$ SNP as might have been expected by virtue of the strong negative feedback relationship between calcitriol and PTH. Other factors, such as age and renal impairment, may have obscured this association in our cohort, but multivariable regression models did not support this conclusion (data not shown).

Three alternate hypotheses might explain the association between $C Y P 27 B 1$ polymorphisms and fracture. Firstly, $C Y P 27 B 1$ is expressed in osteoblasts and has been proposed to mediate osteoblast differentiation [42]. Alteration of this osteoblast $C Y P 27 B 1$ expression might therefore affect skeletal integrity without measurable alteration in circulating calcitriol levels. However, we did not find an association between the -1260 SNP and BUA. Secondly, there is evidence that vitamin D deficiency is associated with the risk of falling [36]. However, we did not find an association between the $-1260 \mathrm{C} C Y P 27 B 1$ allele and fall risk in our cohort. A third possibility is suggested by the fact that $C Y P 27 B 1$ is expressed in the intestine [43], where CDX2 is primarily expressed and known to regulate VDR expression [44]. Since the $-1260 \mathrm{C}$ allele changes a CDX2 binding site within the $C Y P 27 B 1$ promoter, it is conceivable that altered intestinal $C Y P 27 B 1$ expression might affect intestinal calcium absorption, possibly in combination with the VDR promoter CDX2 polymorphism. These hypotheses require further study.

The present findings should be interpreted within the context of strengths and potential weaknesses. This cohort represents an ideal group for the study of genetic associations with fracture since the incidence of fractures in our sample is high, making it possible to identify associations with a smaller number of participants. We note that our study adds to the few genetic markers associated with fracture including the COLIAl Sp1 polymorphism [45] and LRP5 polymorphisms [12]. Nevertheless, this is a relatively small sample size, and we would certainly argue that our findings must be replicated in other, larger cohorts. Moreover, the CYP27B1 variant did not affect BUA; therefore, this gene may only be important for fractures in the vitamin D-insufficient frail elderly, and further studies are required to determine its importance in osteoporosis in general.

In conclusion, these data suggest that the $1 \alpha$-hydroxylase gene $C Y P 27 B 1$ is an important novel candidate contributor to osteoporosis. Given the facts that this enzyme is a critical regulator of vitamin D biosynthesis and that mutations within the coding region of $C Y P 27 B 1$ cause vitamin D-dependent rickets type I [21, 22], the present findings have a strong biologic basis. Since the $1 \alpha$ hydroxylase gene also represents a therapeutic target, the finding reinforces the concept that this is a candidate for further study, in particular to establish whether the polymorphism might predict clinical response to vitamin D therapy $[36,46]$.

Acknowledgments We are grateful to Prof. Howard Morris (Hanson Institute, Adelaide, Australia) for his generous gift of the CYP27B1 promoter-luciferase construct, and to Assoc. Prof. Emma Duncan (Diamantina Institute, University of Queensland, Woolloongaba, Australia) for her helpful review of the manuscript.

Open Access This article is distributed under the terms of the Creative Commons Attribution Noncommercial License which permits any noncommercial use, distribution, and reproduction in any medium, provided the original author(s) and source are credited.

\section{References}

1. Nguyen TV, Blangero J, Eisman JA (2000) Genetic epidemiological approaches to the search for osteoporosis genes. J Bone Miner Res 15:392-401

2. Cummings SR, Nevitt MC, Browner WS, Stone K, Fox KM, Ensrud KE et al (1995) Risk factors for hip fracture in white 
women. Study of Osteoporotic Fractures Research Group. N Engl J Med 332:767-773

3. Deng HW, Chen WM, Recker S, Stegman MR, Li JL, Davies KM et al (2000) Genetic determination of Colles' fracture and differential bone mass in women with and without Colles' fracture. J Bone Miner Res 15:1243-1252

4. Michaelsson K, Melhus H, Ferm H, Ahlbom A, Pedersen NL (2005) Genetic liability to fractures in the elderly. Arch Intern Med 165:1825-1830

5. Nguyen TV, Howard GM, Kelly PJ, Eisman JA (1998) Bone mass, lean mass, and fat mass: same genes or same environments? Am J Epidemiol 147:3-16

6. Makovey J, Nguyen TV, Naganathan V, Wark JD, Sambrook PN (2007) Genetic effects on bone loss in peri- and postmenopausal women: a longitudinal twin study. J Bone Miner Res 22: $1773-1780$

7. Howard GM, Nguyen TV, Harris M, Kelly PJ, Eisman JA (1998) Genetic and environmental contributions to the association between quantitative ultrasound and bone mineral density measurements: a twin study. J Bone Miner Res 13:13181327

8. Tokita A, Kelly PJ, Nguyen TV, Qi JC, Morrison NA, Risteli L et al (1994) Genetic influences on type I collagen synthesis and degradation: further evidence for genetic regulation of bone turnover. J Clin Endocrinol Metab 78:1461-1466

9. Grant SF, Reid DM, Blake G, Herd R, Fogelman I, Ralston SH (1996) Reduced bone density and osteoporosis associated with a polymorphic Sp1 binding site in the collagen type I alpha 1 gene. Nat Genet 14:203-205

10. van Meurs JB, Rivadeneira F, Jhamai M, Hugens W, Hofman A, van Leeuwen JP et al (2006) Common genetic variation of the low-density lipoprotein receptor-related protein 5 and 6 genes determines fracture risk in elderly white men. J Bone Miner Res 21:141-150

11. Styrkarsdottir U, Halldorsson BV, Gretarsdottir S, Gudbjartsson DF, Walters GB, Ingvarsson $T$ et al (2008) Multiple genetic loci for bone mineral density and fractures. $\mathrm{N}$ Engl $\mathrm{J}$ Med 358:2355-2365

12. van Meurs JB, Trikalinos TA, Ralston SH, Balcells S, Brandi ML, Brixen K et al (2008) Large-scale analysis of association between LRP5 and LRP6 variants and osteoporosis. JAMA 299: 1277-1290

13. Richards JB, Rivadeneira F, Inouye M, Pastinen TM, Soranzo N, Wilson SG et al (2008) Bone mineral density, osteoporosis, and osteoporotic fractures: a genome-wide association study. Lancet 371:1505-1512

14. Kiel DP, Demissie S, Dupuis J, Lunetta KL, Murabito JM, Karasik D (2007) Genome-wide association with bone mass and geometry in the Framingham Heart Study. BMC Med Genet 8(Suppl 1):S14

15. Morrison NA, Qi JC, Tokita A, Kelly PJ, Crofts L, Nguyen TV et al (1994) Prediction of bone density from vitamin D receptor alleles. Nature 367:284-287

16. Morrison NA, Qi JC, Tokita A, Kelly PJ, Crofts L, Nguyen TV et al (1997) Prediction of bone density from vitamin D receptor alleles [erratum]. Nature 387:106

17. Cooper GS, Umbach DM (1996) Are vitamin D receptor polymorphisms associated with bone mineral density? A meta analysis. J Bone Miner Res 11:1841-1849

18. Nguyen TV, Center JR, Eisman JA (2008) Pharmacogenetics of osteoporosis and the prospect of individualized prognosis and individualized therapy. Curr Opin Endocrinol Diabetes Obes 15:481-488

19. Holick MF (2003) Vitamin D: a millenium perspective. J Cell Biochem 88:296-307
20. Kain SR, Henry HL (1989) 25-Hydroxyvitamin $D_{3}$ metabolism in mitochondria from primary renal cultures. Mol Cell Endocrinol 64:63-69

21. Fu GK, Lin D, Zhang MY, Bikle DD, Shackleton CH, Miller WL et al (1997) Cloning of human 25-hydroxyvitamin D-1 alphahydroxylase and mutations causing vitamin D-dependent rickets type 1. Mol Endocrinol 11:1961-1970

22. Kitanaka S, Murayama A, Sakaki T, Inouye K, Seino Y, Fukumoto $S$ et al (1999) No enzyme activity of 25-hydroxyvitamin $\mathrm{D}_{3}$ 1alpha-hydroxylase gene product in pseudovitamin $\mathrm{D}$ deficiency rickets, including that with mild clinical manifestation. J Clin Endocrinol Metab 84:4111-4117

23. Bahlo M, Booth DR, Broadley SA, Brown MA, Foote SJ et al (2009) Genome-wide association study identifies new multiple sclerosis susceptibility loci on chromosomes 12 and 20. Nat Genet 41:824-828

24. Bailey R, Cooper JD, Zeitels L, Smyth DJ, Yang JH, Walker NM et al (2007) Association of the vitamin D metabolism gene CYP27B1 with type 1 diabetes. Diabetes 56:2616-2621

25. Lopez ER, Regulla K, Pani MA, Krause M, Usadel KH, Badenhoop K (2004) CYP27B1 polymorphisms variants are associated with type 1 diabetes mellitus in Germans. J Steroid Biochem Mol Biol 89-90:155-157

26. Ramos-Lopez E, Bruck P, Jansen T, Pfeilschifter JM, Radeke HH, Badenhoop K (2007) CYP2R1-, CYP27B1- and CYP24mRNA expression in German type 1 diabetes patients. J Steroid Biochem Mol Biol 103:807-810

27. Lopez ER, Zwermann O, Segni M, Meyer G, Reincke M, Seissler $\mathrm{J}$ et al (2004) A promoter polymorphism of the $C Y P 27 B 1$ gene is associated with Addison's disease, Hashimoto's thyroiditis, Graves' disease and type 1 diabetes mellitus in Germans. Eur J Endocrinol 151:193-197

28. Pani MA, Regulla K, Segni M, Krause M, Hofmann S, Hufner M et al (2002) Vitamin D 1alpha-hydroxylase (CYP1alpha) polymorphism in Graves' disease, Hashimoto's thyroiditis and type 1 diabetes mellitus. Eur J Endocrinol 146:777-781

29. Jennings CE, Owen CJ, Wilson V, Pearce SH (2005) A haplotype of the CYP27B1 promoter is associated with autoimmune Addison's disease but not with Graves' disease in a UK population. J Mol Endocrinol 34:859-863

30. Dawson-Hughes B, Harris SS, Krall EA, Dallal GE (1997) Effect of calcium and vitamin D supplementation on bone density in men and women 65 years of age or older. N Engl J Med 337: 670-676

31. Sambrook PN, Chen JS, March LM, Cameron ID, Cumming RG, Lord SR et al (2004) Serum parathyroid hormone is associated with increased mortality independent of 25-hydroxy vitamin D status, bone mass, and renal function in the frail and very old: a cohort study. J Clin Endocrinol Metab 89:5477-5481

32. Lee PH, Shatkay H (2008) F-SNP: computationally predicted functional SNPs for disease association studies. Nucleic Acids Res 36:D820-D824

33. Gao XH, Dwivedi PP, Choe S, Alba F, Morris HA, Omdahl JL, May BK (2002) Basal and parathyroid hormone induced expression of the human 25-hydroxyvitamin D 1alpha-hydroxylase gene promoter in kidney AOK-B50 cells: role of Sp1, Ets and CCAAT box protein binding sites. Int J Biochem Cell Biol 34:921-930

34. Cox DR (1972) Regression models and life tables. J R Stat Soc (B) $34: 187-220$

35. Eide GE, Gefeller O (1995) Sequential and average attributable fractions as aids in the selection of preventive strategies. J Clin Epidemiol 48:645-655

36. Bischoff-Ferrari HA, Willett WC, Wong JB, Giovannucci E, Dietrich T, Dawson-Hughes B (2005) Fracture prevention with 
vitamin D supplementation: a meta-analysis of randomized controlled trials. JAMA 293:2257-2264

37. Arai H, Miyamoto KI, Yoshida M, Yamamoto H, Taketani Y, Morita K, Kubota M, Yoshida S, Ikeda M, Watabe F, Kanemasa Y, Takeda E (2001) The polymorphism in the caudal-related homeodomain protein $\mathrm{Cdx}-2$ binding element in the human vitamin D receptor gene. J Bone Miner Res 16:1256-1264

38. Fang Y, van Meurs JB, Bergink AP, Hofman A, van Duijn CM, van Leeuwen JP, Pols HA, Uitterlinden AG (2003) Cdx-2 polymorphism in the promoter region of the human vitamin D receptor gene determines susceptibility to fracture in the elderly. J Bone Miner Res 18:1632-1641

39. Uitterlinden AG, Ralston SH, Brandi ML, Carey AH, Grinberg D, Langdahl BL et al (2006) The association between common vitamin D receptor gene variations and osteoporosis: a participant-level meta-analysis. Ann Intern Med 145:255-264

40. Stene LC, Ulriksen J, Magnus P, Joner G (2000) Use of cod liver oil during pregnancy associated with lower risk of type I diabetes in the offspring. Diabetologia 43:1093-1098

41. Liu PT, Stenger S, Li H, Wenzel L, Tan BH, Krutzik SR et al (2006) Toll-like receptor triggering of a vitamin D-mediated human antimicrobial response. Science 311:1770-1773
42. Atkins GJ, Anderson PH, Findlay DM, Welldon KJ, Vincent C, Zannettino AC, O'Loughlin PD, Morris HA (2009) Metabolism of vitamin D3 in human osteoblasts: evidence for autocrine and paracrine activities of 1alpha, 25-dihydroxyvitamin D3. Bone 40:1517-1528

43. Abreu MT, Kantorovich V, Vasiliauskas EA, Gruntmanis U, Matuk R, Daigle K et al (2004) Measurement of vitamin D levels in inflammatory bowel disease patients reveals a subset of Crohn's disease patients with elevated 1,25-dihydroxyvitamin D and low bone mineral density. Gut 53:1129-1136

44. Yamamoto H, Miyamoto K, Li B, Taketani Y, Kitano M, Inoue Y, Morita K, Pike JW, Takeda E (1999) The caudal-related homeodomain protein $\mathrm{Cdx}-2$ regulates vitamin $\mathrm{D}$ receptor gene expression in the small intestine. J Bone Miner Res 14:240-247

45. Ralston SH, Uitterlinden AG, Brandi ML, Balcells S, Langdahl BL, Lips P et al (2006) Large-scale evidence for the effect of the COLIA1 Sp1 polymorphism on osteoporosis outcomes: the GENOMOS study. PLoS Med 3:e90

46. Sambrook PN, Chen JS, March LM, Cameron ID, Cumming RG, Lord SR et al (2004) Serum parathyroid hormone predicts time to fall independent of vitamin D status in a frail elderly population. J Clin Endocrinol Metab 89:1572-1576 